\title{
A Swirling Pipe Flow Course Project
}

\section{Dr. John E Matsson, Oral Roberts University}

John Matsson is a Professor of Mechanical Engineering at Oral Roberts University in Tulsa, OK. He earned M.S. and Ph.D. degrees from the Royal Institute of Technology in Stockholm, Sweden in 1988 and 1994 respectively. 


\title{
A Swirling Pipe Flow Course Project
}

\begin{abstract}
Students designed a rotating pipe flow apparatus for the fluids laboratory. The project was funded by the ASHRAE Senior Undergraduate Project Grant Program. This paper describes a project where a group of undergraduate engineering students in the manufacturing processes, finite element methods and fluid mechanics courses designed, built, and tested a swirling pipe flow apparatus for measurements of friction factors. The overall objective was to engage the students in a design project. The paper will also provide details of assessment and outcomes for the project.

The students had to choose materials, minimize production cost, and determine fabrication techniques for the apparatus. Students designed the apparatus using SolidWorks, and SolidWorks Flow Simulation software was used to simulate the swirling pipe flow.

Students designed a pipe flow apparatus with static mixers, diffuser, settling chamber, honeycomb, screens and a contraction in order to minimize the disturbance level of the flow entering the pipe section. The pipe had a section that could be rotated in order to study the effects of swirling motion on the stability of pipe flow. Students were involved in the building of the apparatus and they performed pressure drop measurements and determined friction factors.
\end{abstract}

\section{Introduction}

This project involved the design, building and testing of a swirling pipe flow laboratory setup for undergraduate engineering students. The laboratory will enable students to conduct hands on measurements of laminar, transitional and turbulent pipe flows with swirl.

Swirling motion and related losses are created in piping systems from common components such as bends, elbows, fittings, flow meters, tees, and valves. Piping systems are frequently included in different engineering designs. The water that we use in our homes is distributed through piping networks. Both air and water that flows through pipes is commonly used in heating, ventilation, air conditioning, and refrigeration applications. Piping has numerous HVAC related applications including sizing of pipes and pump head calculations, see Taylor and McGuire ${ }^{1}$. Pipe flow and piping designs are commonly studied in elementary fluid mechanics and $\mathrm{HVAC}^{2}$ courses in mechanical engineering.

Pipe flow was studied by Reynolds ${ }^{3}$ in his transitional flow studies 125 years ago but is still a puzzle ${ }^{4}$. The flow in a pipe is generally considered to be turbulent for Reynolds numbers $R e=U_{m} D \rho / \mu>2,000$ based on mean velocity $U_{m}$, inner pipe diameter $D$, density $\rho$ and the dynamic viscosity $\mu$ of the fluid. However, transition in pipe flows is highly dependent on the disturbance level of the flow and pipe flow has been shown in carefully controlled experiments ${ }^{5}$ to be laminar up to $R e=100,000$. 
In this project the students designed an apparatus with diffuser, settling chamber, honeycomb, screens and a contraction in order to minimize the disturbance level of the flow entering the pipe section. A short stationary section of the pipe will be followed by a longer section that can be axially rotated in order to study the effects of swirling motion on the stability of pipe flow. Swirl has been shown to be destabilizing for laminar pipeflow ${ }^{6}$ but stabilizing for turbulent pipe flow ${ }^{7}$. Furthermore, in turbulent pipe flow the pressure drop along the pipe is decreasing with increasing rotation rate ${ }^{8}$.

The pipe was made of clear polycarbonate tubing for durability and transparency. The inner diameter of the pipe was $D=44.45 \mathrm{~mm}$ and the total length $L$ of the pipe section is limited to $7.14 \mathrm{~m}$ due to lab space restrictions. This means that the total length of the pipe equals 161 pipe diameters. The hydrodynamic entry length $L_{h}$ is the distance between the pipe entrance and the location where the flow is fully developed. The entry length is approximately given by $L_{h}=0.05 \mathrm{DR} e$ for laminar pipe flow and much shorter in turbulent flow $L_{h}=10 D$. Fully developed laminar pipe flow can be attained in the proposed laboratory project for Reynolds number up to 3,000.

The pressure drop in pipe flow is described by $\Delta P=f L \rho U_{m}{ }^{2} / 2 D$ where $f$ is the DarcyWeisbach friction factor defined as $f=8 \tau_{w} \rho U_{m}{ }^{2}$ and $\tau_{w}$ is the wall shear stress. The Fanning friction factor $C_{f}$ is commonly used and is equal to one-fourth the DarcyWeisbach friction factor. For laminar flow in a circular pipe it can be shown that $f=$ $64 / R e$. The Fanning friction factor for turbulent flow in a smooth pipe is given by $f=$ $0.316 / \operatorname{Re}^{1 / 4}$. For rough pipe flow the friction factor can be determined from the wellknown Moody chart.

The velocity profile for fully developed laminar pipe flow is parabolic in shape but there are four different layers of the turbulent pipe flow velocity profile including viscous sublayer, buffer layer, overlap layer and the turbulent layer. Experimental turbulent pipe velocity profiles are often compared with the power law velocity profile. The influence of rotation on pipe flow is determined by the swirl number $S=U_{w} / U_{m}$ where $U_{w}=\omega D / 2$ is the velocity of the pipe wall and $\omega$ is the angular velocity of the rotating pipe.

\section{Experimental Set-Up}

The contraction design for the pipe flow apparatus is important since it reduces turbulence and velocity fluctuations in the flow ${ }^{9}$. The shape of the contraction is often chosen as a fifth-order polynomial in order to avoid boundary layer separation on the convex part of the contraction and growth of Görtler vortices triggered by the centrifugal force on the concave part of the same contraction. It is well known that such vortices can develop on concave surfaces such as airfoils but also in contractions for pipe flows ${ }^{10}$. The shape of the contraction, see figure 1 , was chosen to be

$$
y(x)=R_{i}-\left(R_{e}-R_{i}\right)\left\lfloor 6\left(\frac{x}{L}\right)^{5}-15\left(\frac{x}{L}\right)^{4}+10\left(\frac{x}{L}\right)^{3}\right\rfloor
$$


where $L=263.4 \mathrm{~mm}$ is the length of the contraction and $R_{i}=67.2 \mathrm{~mm}, R_{e}=D / 2=22.2$ $\mathrm{mm}$ are the inlet and exit radius, respectively.

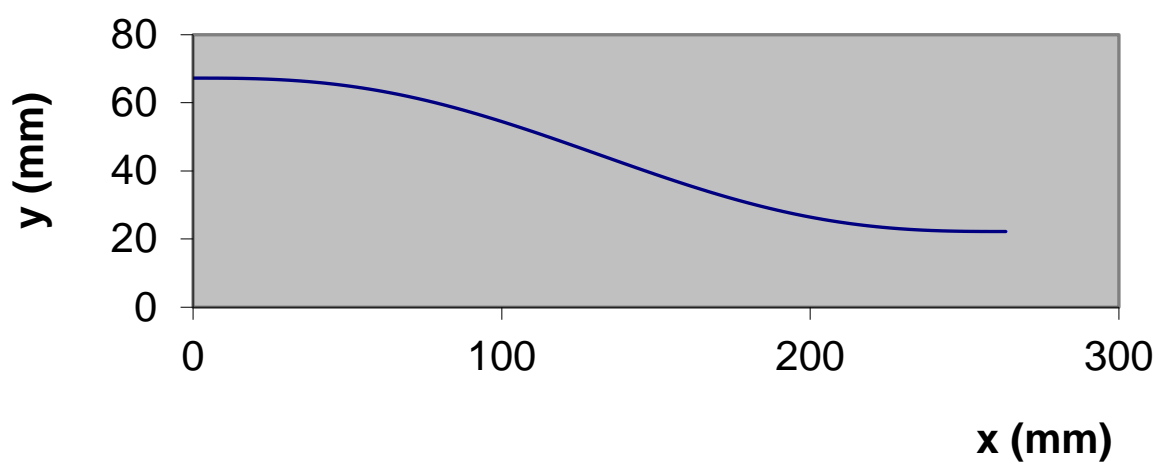

Figure 1 Shape of contraction.

The curvature of the contraction will also be a function of the $x$ coordinate and is shown in figure 2. The curvature is determined by the following equation:

$$
\text { Curvature }=\frac{\frac{d^{2} y}{d x^{2}}}{\left(1+\left(\frac{d^{2} y}{d x^{2}}\right)^{2}\right)^{3 / 2}}
$$

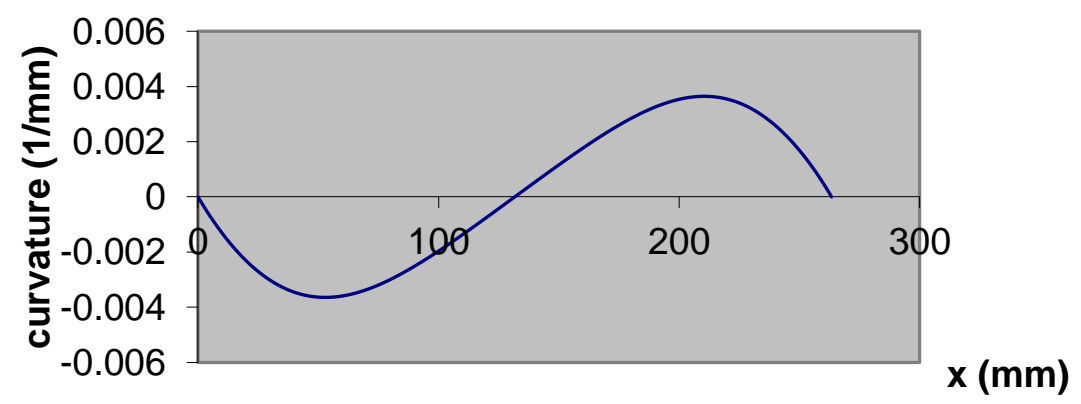

Figure 2 Curvature along the length of the contraction.

The Görtler number Go is important since it predicts the appearance of streamwise vortices in the contraction above a certain value of the Görtler number defined as

$$
\begin{aligned}
& G O=\left(\frac{U_{m} \delta}{v}\right) \sqrt{\frac{\delta}{R}} \\
& \delta=\sqrt{\frac{v \ell}{U_{m}}}
\end{aligned}
$$


where $U_{m}(x)$ is the mean velocity that varies along the contraction, $v$ is the kinematic viscosity of the fluid, $\delta$ is the boundary layer thickness, $R=-1 /$ curvature is the radius of curvature of the wall, and $\ell$ is the streamwise position along the contraction wall. The Görtler number can be rewritten as

$$
\begin{aligned}
& G o=\left(\frac{U_{m} \ell}{v}\right)^{1 / 4} \sqrt{\frac{\ell}{R}} \\
& \ell=\int_{0}^{x} \sqrt{1+\left(\frac{d y}{d x}\right)^{2}} d x
\end{aligned}
$$

We see in figure 3 that the Görtler number reaches a maximum value of $G o=3.73$ at $x=$ $91 \mathrm{~mm}$. The critical Görtler number found from other experiments is around 2 so we see that this value is exceeded in the region $35 \mathrm{~mm}<x<125 \mathrm{~mm}$ or $34 \%$ of the total length of the contraction. This is of some concern but would require extensive efforts in order to rectify ${ }^{10}$ and is beyond the scope of the present study. Figure 3 corresponds to a Reynolds number $R e=12,000$ based on the inner diameter of the pipe at the end of the contraction. Positive Görtler numbers are present in $50 \%$ of the total length of the contraction as shown in figure 3 . As the flow proceeds beyond $x=125 \mathrm{~mm}$, the Görtler number decreases rapidly and the growth of Görtler vortices will not be sustained.

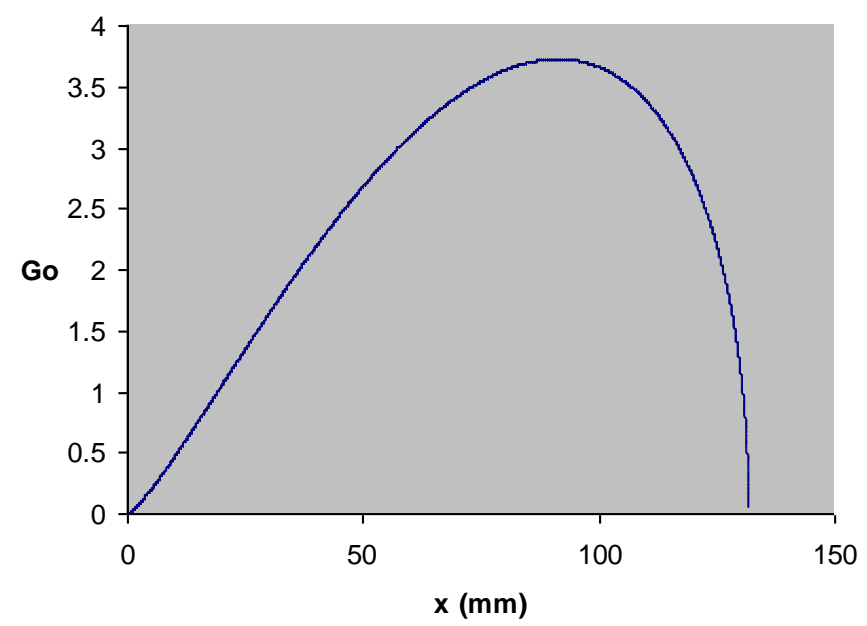

Figure 3 Görtler number variation along the contraction wall $(\operatorname{Re}=12,000)$.

The area ratio (or contraction ratio) $C R$ of the contraction is defined as the ratio between the inlet area and the outlet area of the contraction and is often chosen in the region $5<$ $C R<10$. In our case the area ratio $C R=9.15$.

$$
C R=\frac{R_{i}^{2}}{R_{e}^{2}}
$$


The following figure 4a) shows the SolidWorks ${ }^{\circledR}$ model of the contraction made of fiberglass and resin, see figure 4b). A plug of wood was machined to the shape of the contraction and the final contraction was completed around the plug by the department technician using several layers of fiberglass and resin. Gelcoat was used to achieve a high-quality finish for the contraction.
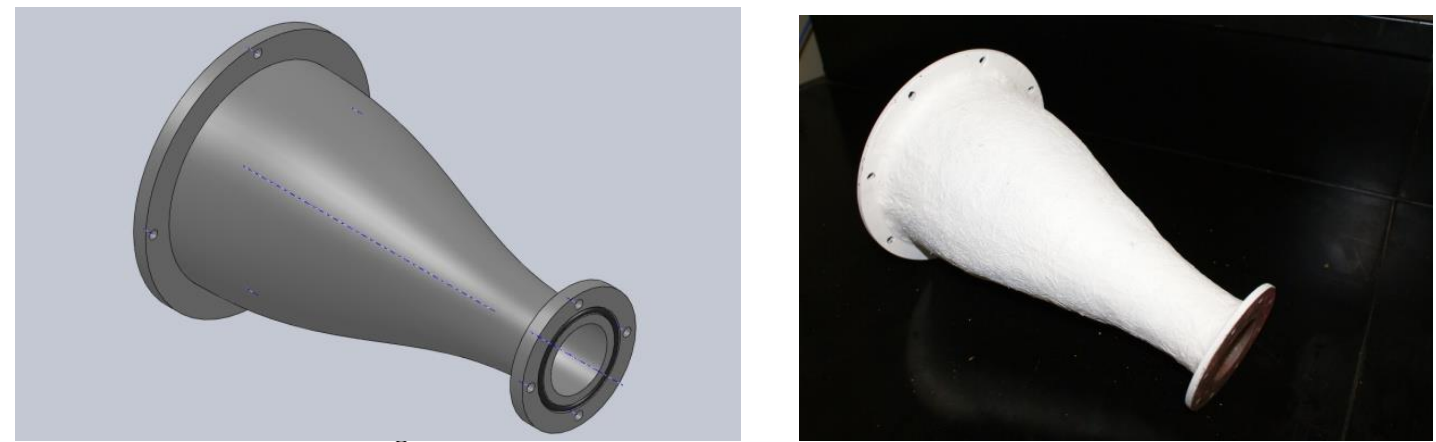

Figure 4a) SolidWorks ${ }^{\circledR}$ model of contraction. Figure 4b) Actual fabricated contraction

The objective of the settling chamber is to create a spatially uniform fluid flow. A number of screens and a honeycomb were therefore placed in the settling chamber for further improvements of the flow condition. The honeycomb will reduce velocity fluctuations in the transverse direction. The settling chamber consists of six sections of polycarbonate stacked on each other with a total length of $287 \mathrm{~mm}$ and o-rings in between each section. Eight threaded $1 / 4$ inch rods with nuts are holding the complete settling chamber together, see figures $5 a)-5 b$ ). The first part from the blower is a diffuser section with a $25^{\circ}$ top angle. After the diffuser, there are five more sections including a perforated polycarbonate plate, a clear polycarbonate honeycomb section 50 $\mathrm{mm}$ in length and with a $6.35 \mathrm{~mm}$ cell size, two fine stainless steel screens $(0.03 \mathrm{~mm}$ wire diameter, $50 \mathrm{mesh} / \mathrm{inch})$, and three coarse stainless steel screens $(0.23 \mathrm{~mm}$ wire diameter, 14 mesh/inch $)^{11}$.

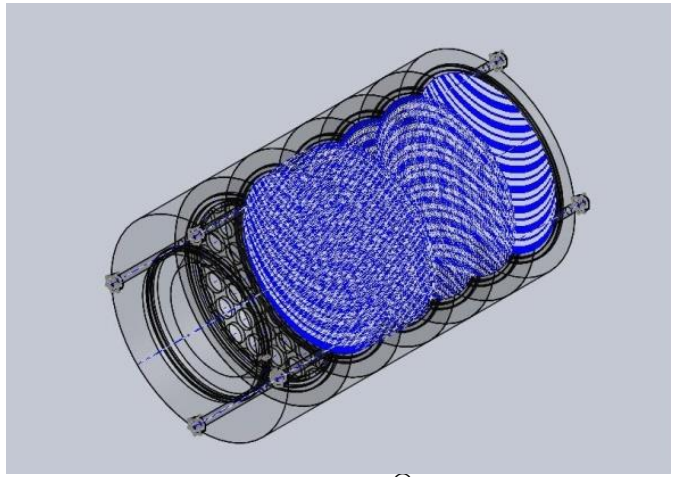

Figure 5a) SolidWorks ${ }^{(B)}$ settling chamber

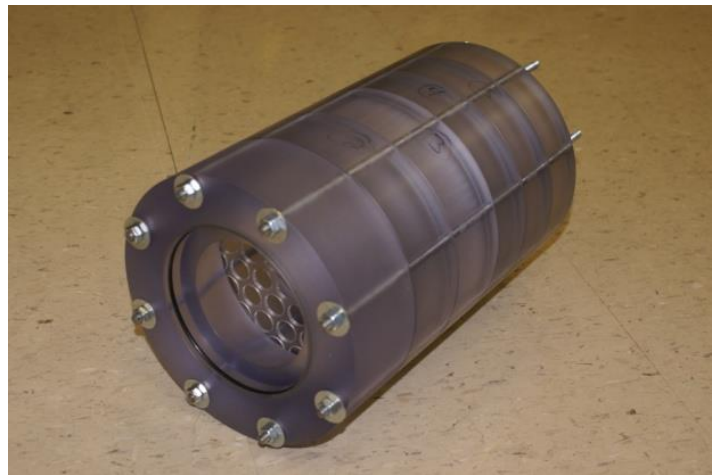

Figure 5b) Finished settling chamber

In figure 6 we see the blower, settling chamber, and contraction. Figures 7a) and 7b) are showing the electric motor and belt drive that is spinning the pipe section, and finally figure 8 is showing the finished setup for swirling pipe flow in air. The blower used in this experiment is a Koala B-Air 1-hp (Model \# KP1200) with a maximum airflow rate of 634 CFM. 
The first pipe section after the contraction is a $1626 \mathrm{~mm}$ (36.6 diameters) long nonrotating pipe. This section is followed by a $4877 \mathrm{~mm}$ (109.7 diameters) long rotating pipe section. The last pipe section is non-rotating and $635 \mathrm{~mm}$ (14.3 diameters) long. At the end of this section is a vane anemometer (Dwyer VT-200) installed for the measurement of the volume flow rate. Pressure taps are installed before and after the spinning pipe section for measurements of the pressure drop along the pipe. Also, a Pitot tube attached to a traversing mechanism is installed at the pipe opening for measurements of velocity profiles. Leakage in between the rotating and non-rotating pipe sections was prevented by the use of spring loaded shaft seals. An electric motor and drive (Baldor Vector ZDM3661T, $3 \mathrm{hp}, 1800 \mathrm{rpm}$ and Baldor Vector Drive Series 18H) are used for rotation of the pipe (geared 2:1), see figures $7 a$ ) and $7 b$ ).

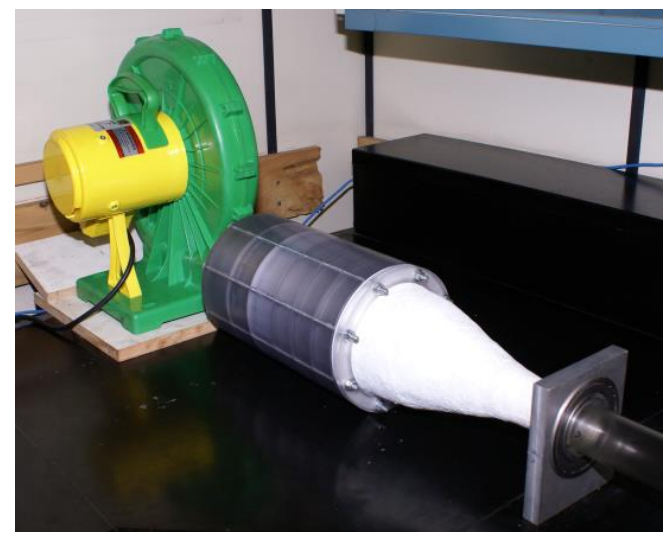

Figure 6 Blower, settling chamber, and contraction

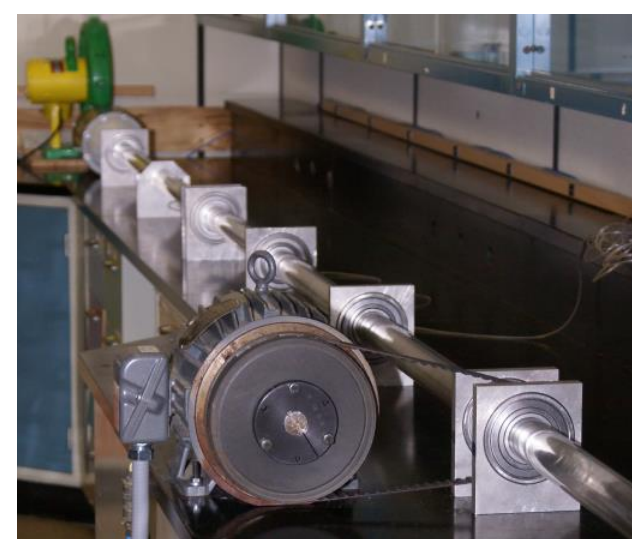

Figure 7a) Motor and pipe section

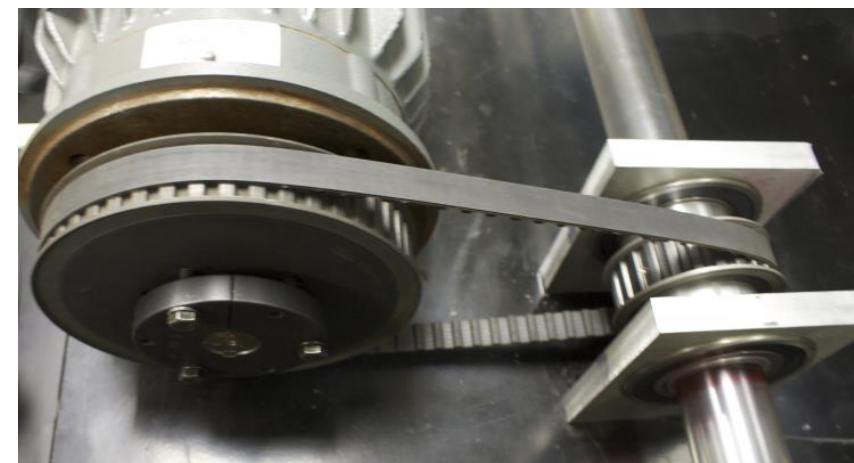

Figure 7b) Detail of motor-belt-pipe connection

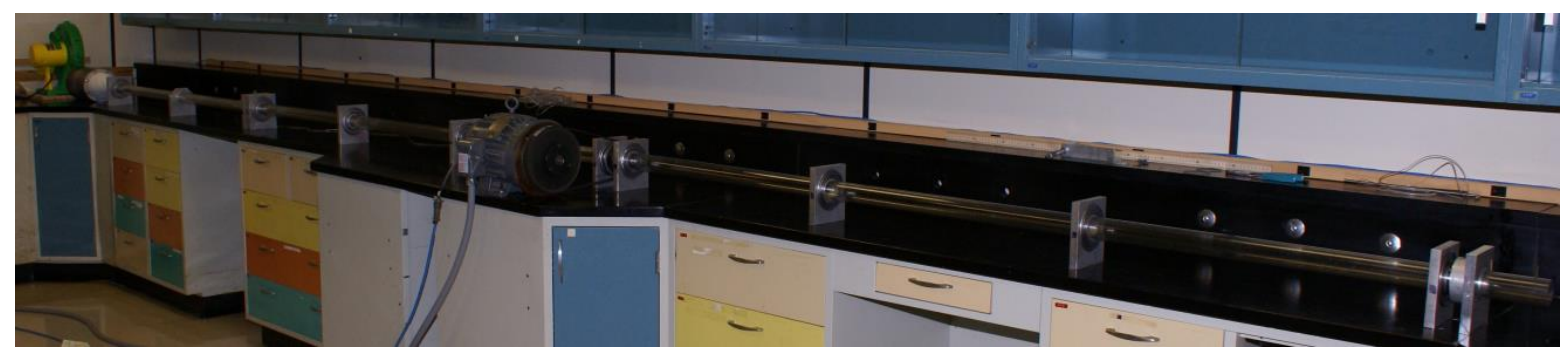

Figure 8 Completed experimental setup for air 


\section{SolidWorks ${ }^{\circledR}$ Flow Simulation Results}

SolidWorks ${ }^{\circledR}$ flow simulations ${ }^{12}$ have been completed for the contraction. The results shown here are for Reynolds number $R e=12,000$ based on the inner diameter of the pipe. Figures $9 a$ ) and $9 b$ ) are showing cut plots along the contraction centerline for the velocity and pressure fields, respectively. In figure 10 is a comparison shown between simulation results and theory for the velocity along the contraction centerline. It is seen that there is a close agreement between simulations and theory. The velocity is increasing as the flow passes the contraction from the larger area inlet to the smaller exit area. Figure 11 is showing the corresponding pressure variation along the contraction centerline. The pressure is decreasing along the contraction. There are no results available for a theoretical comparison with simulations since the inlet velocity profile is not fully developed. In figure 12 are velocity profiles shown at different streamwise locations in the contraction. It is seen that the maximum velocity of the different profiles is increasing as the flow proceeds through the contraction. Furthermore, it is clear that the contraction is too short in order for fully developed flow to appear along its length. Therefore, a stationary pipe section following the contraction has been installed in the experimental set-up in order for fully developed flow to develop at low Reynolds numbers for laminar flow.

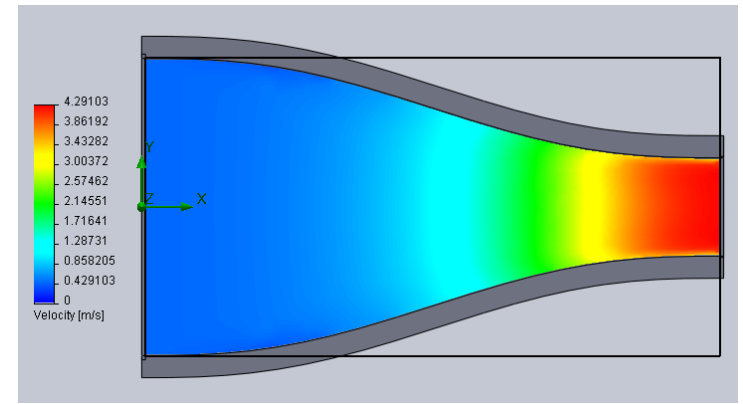

a)

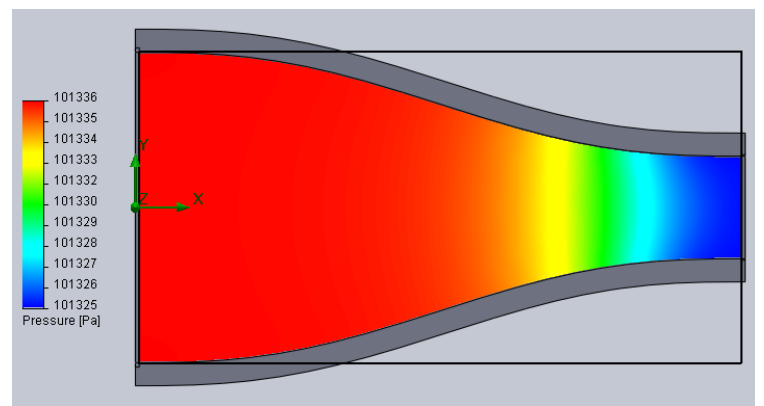

b)

Figure 9 Flow simulation results for the contraction at $R e=12,000$.

a) Velocity filed, b) Pressure field.

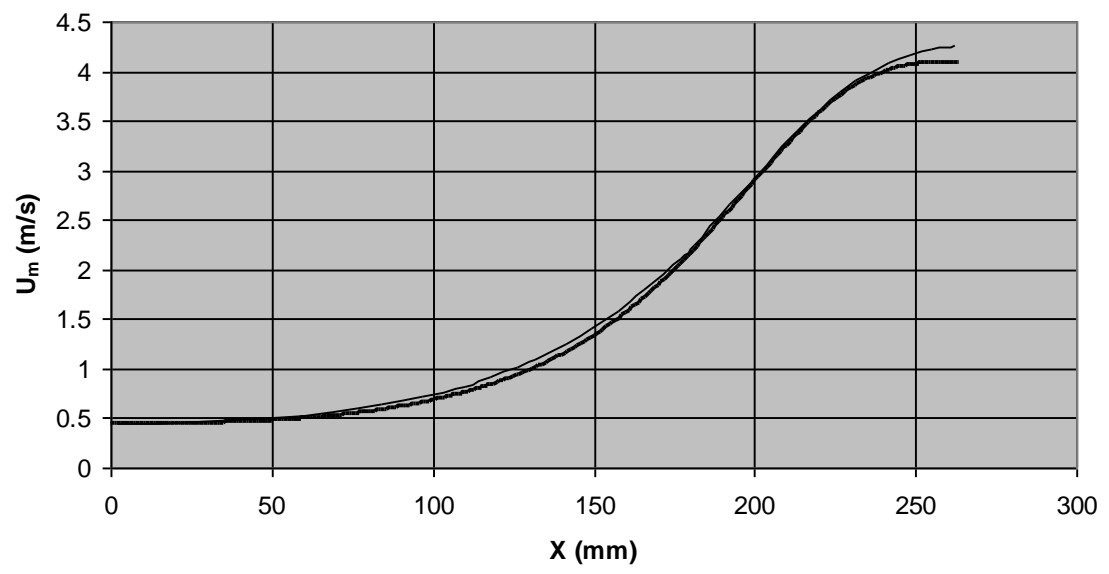

Figure 10 A comparison between SolidWorks ${ }^{\circledR}$ Flow Simulation results (thin line) and theory for velocity variation along contraction centerline. 


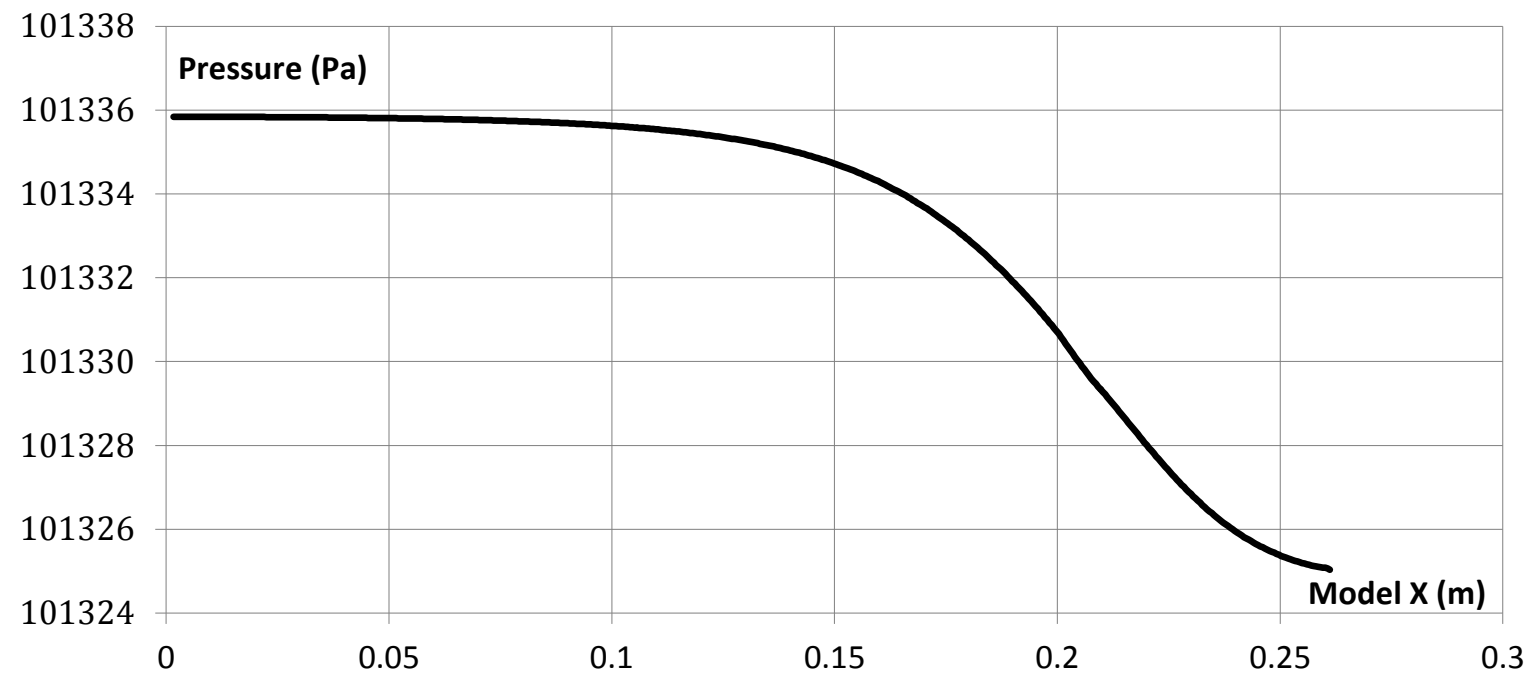

Figure 11 SolidWorks ${ }^{\circledR}$ Flow Simulation results of pressure variation along contraction centerline.

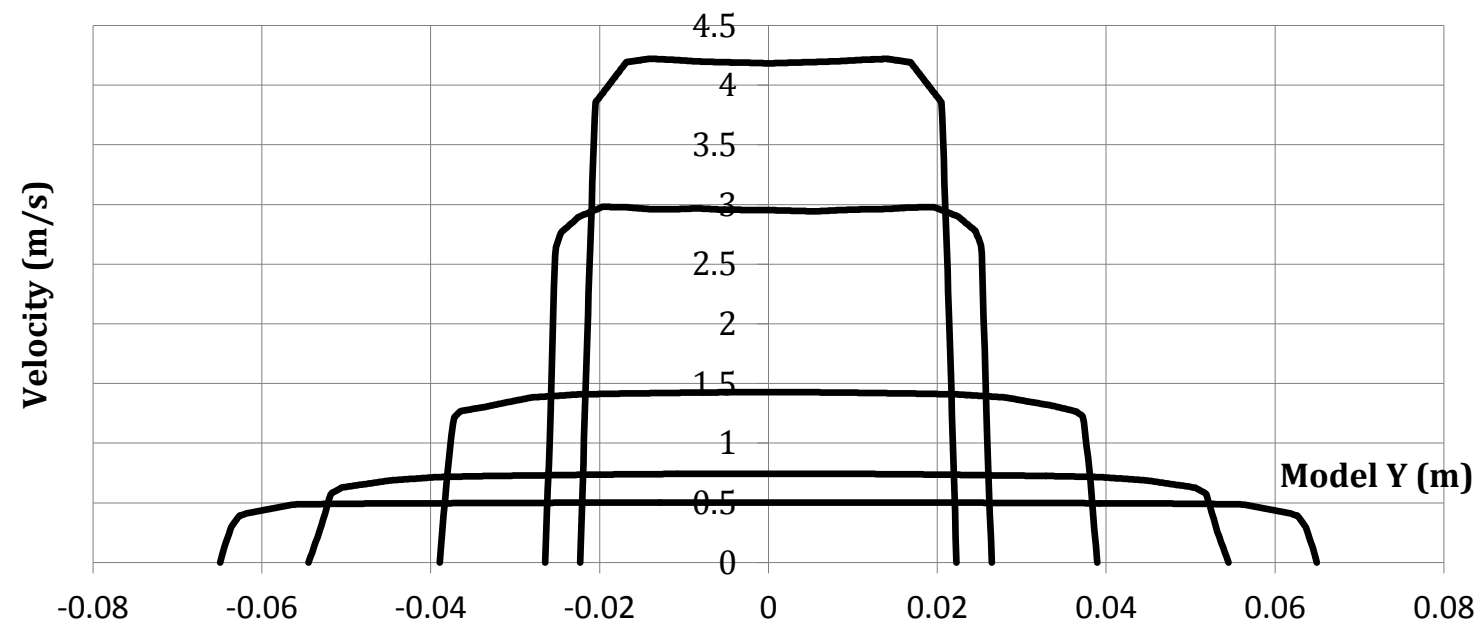

Figure 12. SolidWorks ${ }^{\circledR}$ Flow Simulation velocity profiles at different streamwise locations $(X=50,100,150,200$, and $250 \mathrm{~mm})$ along the contraction

\section{Student Involvement}

Students have been involved in all phases of this project including design, building and testing of the swirling pipe flow project. All students were required to complete a design project. Design and building was accomplished in the manufacturing and finite element methods courses during fall semester while testing was completed in the fluid mechanics course during the following spring semester. There were a total of 13 different students involved in at least one of the courses as listed in Table 1a) and Table 1b). Two of the four students worked on the project in both the finite element and manufacturing processes courses. These students had completed the fluid mechanics course in an earlier semester and received additional training in the use of the SolidWorks ${ }^{\circledR}$ Flow Simulation software in this previous course. The remaining two students from each fall course were 
also working on the project during the following spring fluid mechanics course.

\begin{tabular}{|l|l|l|l|}
\hline Course & $\begin{array}{l}\text { Finite } \\
\text { Element } \\
\text { Methods }\end{array}$ & $\begin{array}{l}\text { Fluid } \\
\text { Mechanics }\end{array}$ & $\begin{array}{l}\text { Manufacturing } \\
\text { Processes }\end{array}$ \\
\hline $\begin{array}{l}\text { Number of } \\
\text { Students }\end{array}$ & 4 & 11 & 4 \\
\hline
\end{tabular}

Table 1a) Total number of students involved in the project for different courses

\begin{tabular}{|l|c|c|c|}
\hline & $\begin{array}{l}\text { Finite } \\
\text { Element } \\
\text { Methods }\end{array}$ & $\begin{array}{l}\text { Fluid } \\
\text { Mechanics }\end{array}$ & $\begin{array}{l}\text { Manufacturing } \\
\text { Processes }\end{array}$ \\
\hline Student 1 & $\mathrm{x}$ & & $\mathrm{x}$ \\
\hline Student 2 & $\mathrm{x}$ & & $\mathrm{x}$ \\
\hline Student 3 & & $\mathrm{x}$ & $\mathrm{x}$ \\
\hline Student 4 & & $\mathrm{x}$ & \\
\hline Student 5 & $\mathrm{x}$ & $\mathrm{x}$ & \\
\hline Student 6 & & $\mathrm{x}$ & \\
\hline Student 7 & $\mathrm{x}$ & $\mathrm{x}$ & \\
\hline Student 8 & & $\mathrm{x}$ & \\
\hline Student 9 & & $\mathrm{x}$ & \\
\hline Student 10 & & $\mathrm{x}$ & \\
\hline Student 11 & & $\mathrm{x}$ & \\
\hline Student 12 & & $\mathrm{x}$ & \\
\hline Student 13 & & $\mathrm{x}$ & \\
\hline
\end{tabular}

Table 1b) Distribution of students in project courses

The students worked on the course project a minimum of one hour per week outside of scheduled class hours. Weekly progress reports were submitted and contributed to $50 \%$ of the project grade while the project report contributed to the remaining $50 \%$ of the project grade. The project has since it was completed been included as a lab titled "Friction Factors in Pipe Flow" in the fluid mechanics course. 19 students will be using the swirling pipe flow lab during the spring 2014 semester.

Students designed the apparatus using SolidWorks ${ }^{\circledR}$ software and the design has been directed towards a minimum turbulence level of the flow entering the pipe. SolidWorks ${ }^{\circledR}$ flow simulations of the flow field have been determined. Figure 13 is showing the Fanning friction factor versus mesh level for flow simulations of an eight-foot long pipe section without swirl. It is seen that the higher the mesh level, the finer the mesh and the closer the friction factor is to empirical results. The flow simulation was for fully developed flow with an inlet velocity boundary condition and a static pressure boundary condition at the outlet. 


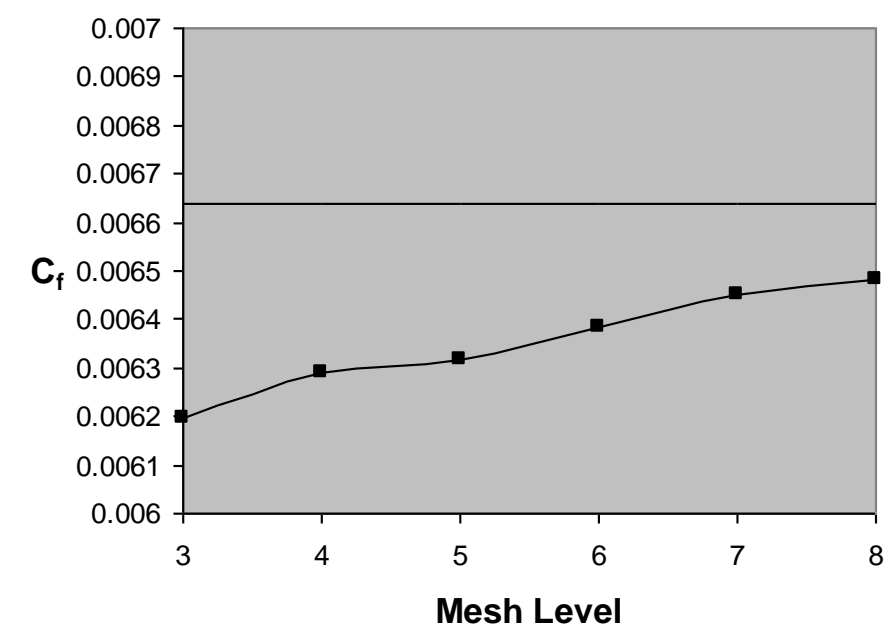

Figure 13 Fanning friction factor versus mesh level at $R e=20,000$. Line with markers corresponds to SolidWorks ${ }^{\circledR}$ Flow Simulation results and the full line corresponds to empirical results for turbulent flow in a smooth pipe.

Moreover, students have been involved in the building of the apparatus under supervision of the technician at the engineering department. An example of this is shown in figures 14a) and 14b) where the students machined bearing housings for the ball bearings and sleeves that were fitted to the polycarbonate tube. Finally, the students tested the flow quality of the pipe flow and performed friction factor measurements ${ }^{13,14}$. Figure 15 is showing the traversing mechanism and micrometer used for movement of the Pitot tube inside the pipe for measurements of velocity profiles.
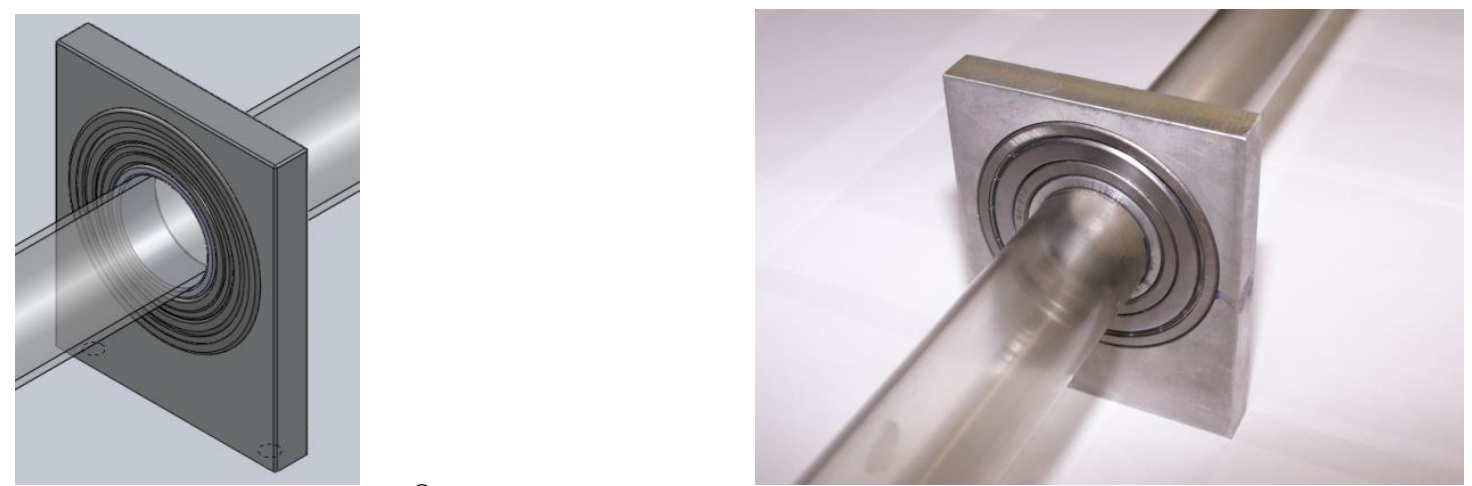

Figure 14a) SolidWorks ${ }^{\circledR}$ bearing housing Figure 14b) Bearing housing assembly 


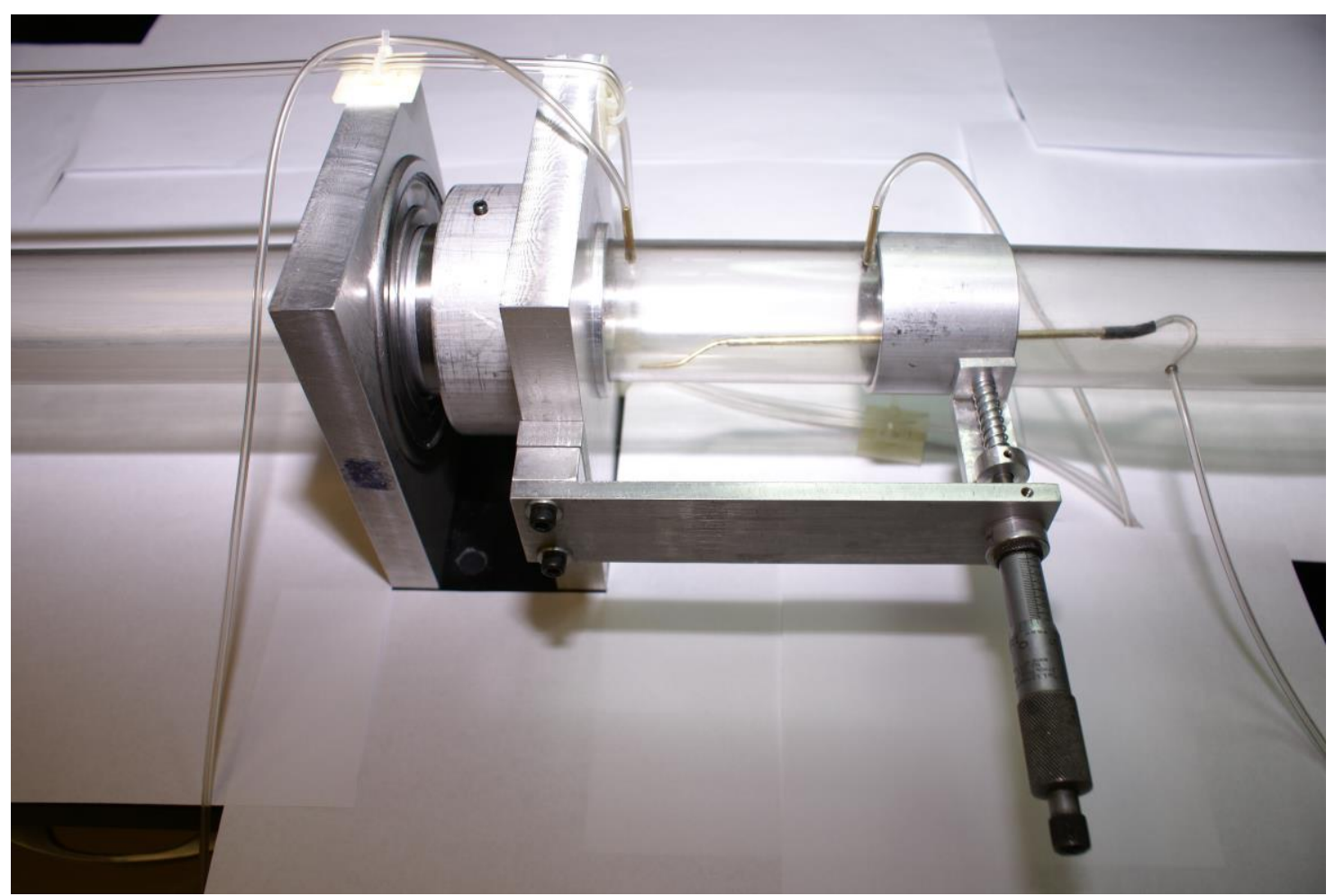

Figure 15 Traversing unit and Pitot tube used for measurements

The experiments consisted of different parts. First, measurements were made of the pressure drop and the associated friction factors were calculated for the pipe flow without swirl and a comparison was made with published data. It turned out that the transitional Reynolds number between laminar and turbulent flow for the pipe apparatus was dependent on the number of sections that were include in the settling chamber. The transitional Reynolds number increased from $R e=2,000$ to $R e=40,000$ depending on the number of sections added to the settling chamber. In the results presented in this paper only three of the sections including the diffuser and honeycomb sections were installed. As we can see in figure 16, the transitional Reynolds number for this configuration is at $R e=28,000$. We can also note that the experimental results follow the theoretical friction factor variation with Reynolds number $f=64 / \operatorname{Re}$ up to Reynolds number $R e=3,000$. This the highest Re for which the laminar flow is fully developed in the present experimental set-up. At higher Reynolds numbers with laminar flow we see that the friction factor varies with Reynolds number as $f=4.6 / \mathrm{Re}^{2 / 3}$. The higher friction factor is related to a non-fully developed laminar pipe flow. At Reynolds number $R e=28,000$ the flow transitions from laminar to turbulent flow as indicated by a jump in friction factor to higher values. Our experimental data in the turbulent region closely follow the $f=$ $0.3164 / \mathrm{Re}^{1 / 4}$ relation. As compared with the Oregon group ${ }^{14}$ we see that the flow in our experiments transitions to turbulent flow at a Reynolds number almost ten times higher. 


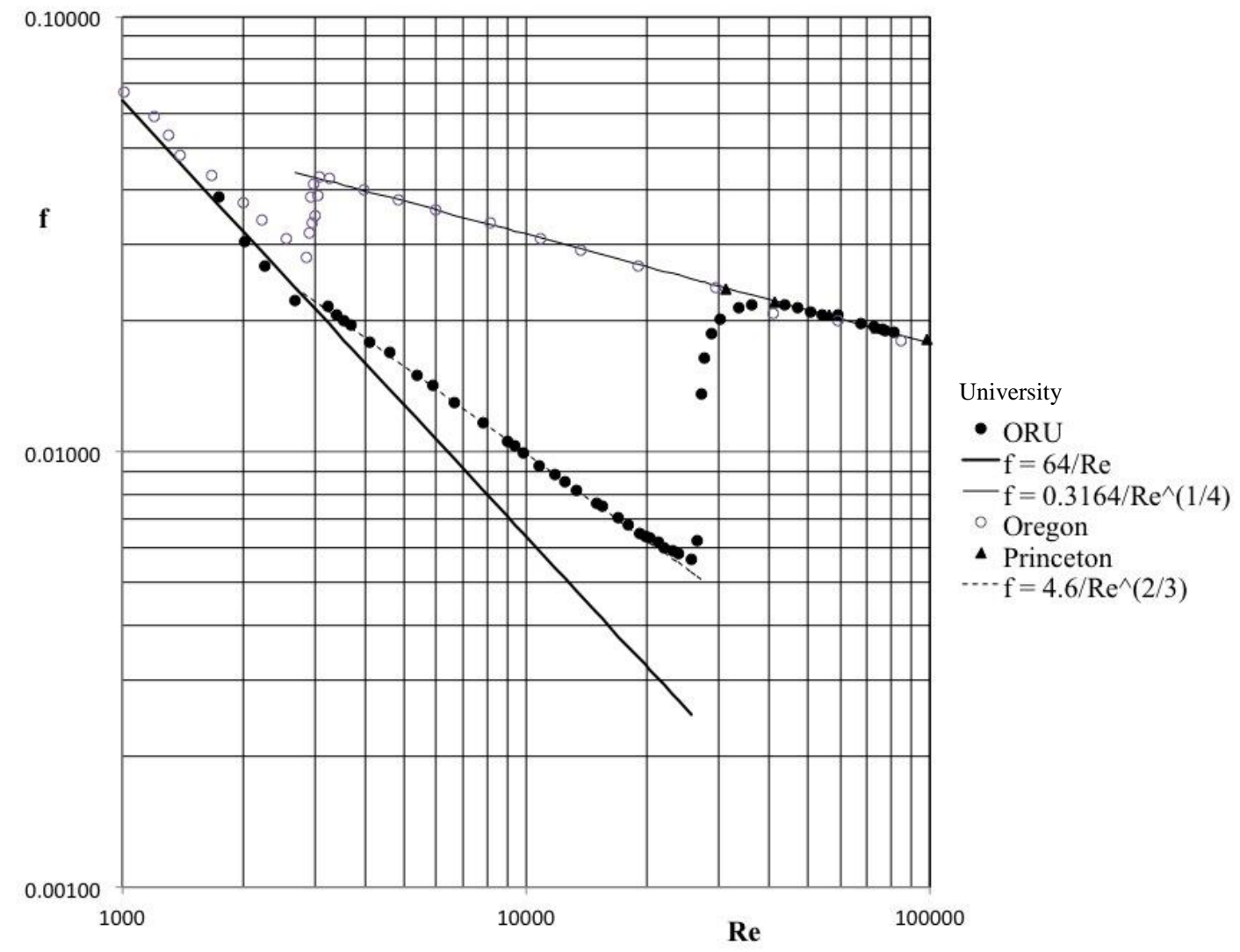

Figure 16 Experimental friction factor versus Reynolds number without swirl

\section{Assessment and Outcomes for the Project}

The overall objective was to engage the students in a design project. This project was therefore included in the manufacturing processes and finite element methods courses during the fall semester and the fluid mechanics course during the following spring semester. Each student wrote an individual project report at the end of the fall semester in the finite element methods course. Students completed a machining lab and wrote individual lab reports in the manufacturing processes course. In this lab the students machined the bearing housings for the ball bearings that were attached to the spinning pipe section. For the fluid mechanics course, the students wrote the final project report that was submitted to the donor of the grant for the project. Furthermore, the students in the fluid mechanics course completed a friction factors in pipe flow lab and wrote individual lab reports. The course project contributed to $5 \%$ and $10 \%$ of the final grades in the finite element methods and fluid mechanics courses, respectively. The project related lab reports in the manufacturing processes and fluid mechanics courses contributed to $3 \%$ and $5 \%$ of the final grade, respectively. An overview of the final grade contribution of project and related labs for different courses is shown in table 2. 


\begin{tabular}{|l|l|l|l|}
\hline & $\begin{array}{l}\text { Finite Element } \\
\text { Method }\end{array}$ & Fluid Mechanics & $\begin{array}{l}\text { Manufacturing } \\
\text { Processes }\end{array}$ \\
\hline Lab report & ----- & $5 \%$ & $3 \%$ \\
\hline Project report & $5 \%$ & $10 \%$ & ----- \\
\hline
\end{tabular}

Table 2. Final grade contribution of project and related labs for different courses

The student performance was assessed based on written reports but also on weekly progress reports and achievements in relation to the definition of completeness for the project. In the weekly progress reports, students provided evidence of work completed during the past week and include an updated time line for the project. The project reports generally included an abstract followed by an introduction to the topic, a theory section, a results section, a section with conclusions, recommendations for the project, and references.

The project described in this paper contributed to certain university course outcomes and proficiencies/capacities such as intellectual creativity, critical thinking, communication skills, leadership capacity and interpersonal skills as shown in Table 3. Table 3 is copied from the syllabus of the fluid mechanics course as an example. The project was not the only component that contributed to Table 3 for this course. Other evaluation procedures such as quizzes, homework problems, labs, exams, and final exam determined the final level of contribution as shown in the table.

Significant Contribution - Addresses the outcome directly and includes targeted assessment Moderate Contribution - Addresses the outcome directly or indirectly and includes some assessment Minimal Contribution - Addresses the outcome indirectly and includes little or no assessment No Contribution - Does not address the outcome

\begin{tabular}{|l|c|l|l|l|}
\hline $\begin{array}{l}\text { Outcome - Intellectually } \\
\text { Plert }\end{array}$ & $\begin{array}{l}\text { Significant } \\
\text { Contribution }\end{array}$ & $\begin{array}{l}\text { Moderate } \\
\text { Contribution }\end{array}$ & $\begin{array}{l}\text { Minimal } \\
\text { Contribution }\end{array}$ & $\begin{array}{l}\text { No } \\
\text { Contribution }\end{array}$ \\
\hline Critical thinking & $\mathrm{X}$ & & $\mathrm{X}$ & \\
\hline Information literacy & & & $\mathrm{X}$ & \\
\hline $\begin{array}{l}\text { Global \& historical } \\
\text { perspectives }\end{array}$ & & & $\mathrm{X}$ \\
\hline Aesthetic appreciation & & $\mathrm{X}$ & $\mathrm{X}$ & \\
\hline Intellectual creativity & & & & \\
\hline Communication skills & & & & \\
\hline Interpersonal skills & & & & \\
\hline Leadership capacity & & & & \\
\hline
\end{tabular}

Table 3. Fluid mechanics course inventory for university student learning outcomes 
The student learning outcomes specific for the manufacturing processes course are to discuss and explain

1. Casting processes

2. Heat treating and metal strengthening processes

3. Hot and cold working of metals

4. Joining: welding and adhesive bonding

5. Machining

6. Plastic processing: molding and extruding

7. Costing and operations planning

The project included components related to outcomes 2 - 5, and 7.

The students provided feedback on the project in lab reports, course project reports, and the final project report that was submitted to ASHRAE. The labs and course project reports included a separate section where the students provided recommendations for improvement of the labs and project. In the final project report the students included a section on project recommendation and a separate section on student benefits.

Project recommendations from students included adding smoke visualizations in air and modifying the experimental set up to include water as the working fluid and using dye in water for visualizations. A problem that arose during initial testing was overheating of the bearings. This was rectified with improved alignment of the spinning pipe section. The students recommended limiting the rotational velocity of the pipe in order to avoid overheating. Student benefits included enabling the students to conduct measurements of laminar and turbulent pipe flows with swirling motion. Furthermore, to the students benefit the project provided an opportunity to understand the effects of a rotating pipe flow system with various types of flows at different swirl numbers. While students gained insight into the experimentation of rotating pipe flow, insight into the design process and flow simulations was also obtained. The direct comparison between flow simulations and experiments was beneficial to the engineering students.

Figure 17a) is showing student results on the written reports for the machining of bearing housing lab in the manufacturing processes course. In figure 17b) is the score distribution shown for individual project reports in the finite element methods course and finally figure 17c) is showing student scores for the friction factors in pipe flow lab report in the fluid mechanics course.

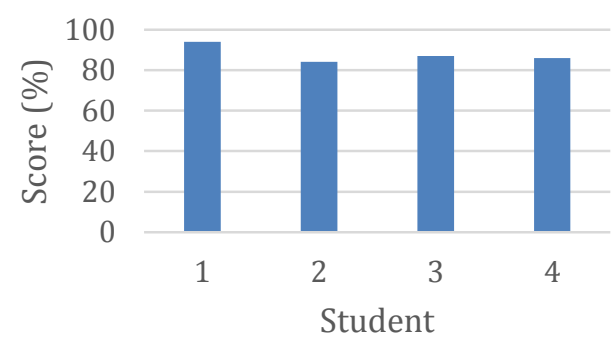

Figure 17a) Score distribution for machining lab in manufacturing processes course 


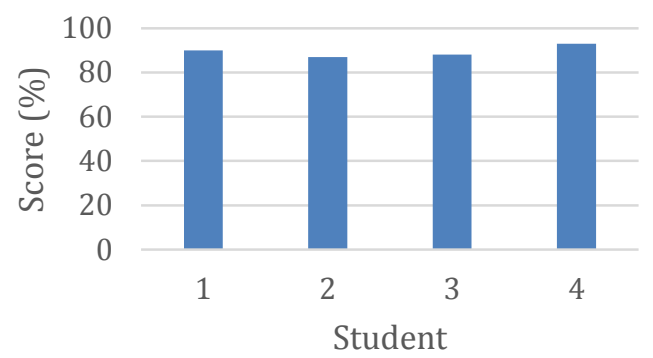

Figure 17b) Score distribution for finite element methods project

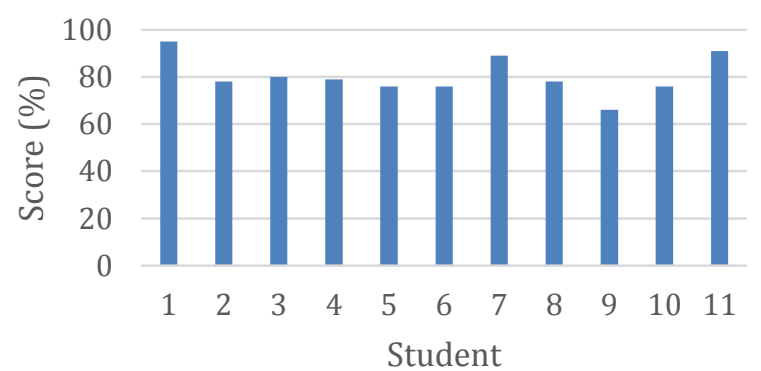

Figure 17c) Score distribution for fluid mechanics friction factor in pipe flow lab

Finally, the author learned from supervising the design project and working with students the importance of a clear and concise plan of attack, project report assignments, final goal and expectations be given and stated in the beginning of the semester. Moreover, it is important to give students sufficient time to work on the project and to give them a chance to compile all the necessary data for the project report.

\section{Conclusions}

This paper has shown a swirling pipe flow project by undergraduate students. It was initiated as a project in the manufacturing processes and finite element method courses and has been used for friction factor pipe flow measurements in the fluid mechanics course. The cost of building the experimental set-up described in this paper was $\$ 1,942$ (excluding electric motor and drive). The project cost is detailed in Table 4.

\begin{tabular}{|c|l|l|c|}
\hline Item & \multicolumn{1}{|c|}{ Description } & \multicolumn{1}{c|}{ Vendor } & Price \\
\hline Ball Bearings & $\begin{array}{l}\text { 10 PCS. 6212-ZZ SHIELDED BALL } \\
\text { BEARING ABEC 3/C3 }\end{array}$ & $\begin{array}{c}\text { Fremont } \\
\text { Industrial } \\
\text { Supply }\end{array}$ & $\$ 77.15$ \\
\hline Belt & $\begin{array}{l}\text { H (HEAVY) BELT 1/2 INCH } \\
\text { PITCH, 3/4 INCH WIDE, TRADE }\end{array}$ & McMaster Carr & $\$ 20.64$ \\
\hline Blower & KOALA BLOWER KP1200 & B-Air Blowers & $\$ 125.00$ \\
\hline & $\begin{array}{l}\text { QUICK-DISCONNECT (QD) } \\
\text { BUSHING STYLE SK, 5/8 INCH } \\
\text { BORE, 3/16 INCH X 3/32 INCH } \\
\text { BEYWhing }\end{array}$ & McMaster Carr & $\$ 25.09$ \\
\hline
\end{tabular}




\begin{tabular}{|c|c|c|c|}
\hline Polycarbonate Honeycomb & $\begin{array}{l}\text { 50 MM LONG, } \\
4 \text { \& } 7 \text { MM CELL SIZE }\end{array}$ & Plascore & $\$ 134.25$ \\
\hline Polycarbonate Round Bar & 2 FT LONG, 7 INCH DIAMETER & $\begin{array}{l}\text { Plastic Supply } \\
\& \text { Fabrication }\end{array}$ & $\$ 713.84$ \\
\hline Polycarbonate Tubing & $\begin{array}{l}1.75 \text { ID X } 2.00 \text { OD X } 16 \text { FOOT, } \\
\text { CLEAR EXTRUDED }\end{array}$ & $\begin{array}{l}\text { Professional } \\
\text { Plastics, Inc. }\end{array}$ & $\$ 207.87$ \\
\hline Pulleys & $\begin{array}{l}\text { PULLEYS FOR H (HEAVY) } \\
\text { TIMING BELTS } 1 / 2 \text { INCH PITCH }\end{array}$ & McMaster Carr & $\$ 151.56$ \\
\hline Round Bar & $\begin{array}{l}3 \text { INCH DIA. ROUND BAR 6061- } \\
\text { T6 ALUMINUM ROUND }\end{array}$ & Metals Depot & $\$ 41.50$ \\
\hline Spring Loaded Seal & GRAPHITE PTFE, $3 / 16$ & McMaster Carr & $\$ 147.40$ \\
\hline Stainless Steel Screens & $\begin{array}{l}50 \text { MESH T316 .0012 INCH WIRE } \\
\text { DIA., 14 MESH T316 .009 INCH } \\
\text { WIRE DIA. }\end{array}$ & TWP, Inc. & $\$ 156.00$ \\
\hline Shipping Charges & & & $\$ 141.41$ \\
\hline Total & & & $\$ 1,941.71$ \\
\hline
\end{tabular}

Table 4. Detailed project cost

\section{Bibliography}

1. Taylor S.T. and McGuire M. "Sizing pipe using life-cycle costs. ", ASHRAE Journal, 24 - 32, October 2008.

2. McQuiston F.C., Parker J.D. and Spitler J.D. "Heating, Ventilating and Air Conditioning: Analysis and Design.", 6th Edition, Wiley, 2004.

3. Reynolds O. "An experimental investigation of the circumstances which determine whether the motion of water shall be direct or sinuous, and of the law of resistance in parallel channels.", Phil. Trans. Roy. Soc. 174, 935 - 982, 1883.

4. Mullin T. "Experimental studies of transition to turbulence in a pipe." Ann. Rev. Fluid Mech., 43, 1 24, 2011.

5. Draad A. A. and Nieuwstadt F. T. "The Earth's rotation and laminar pipe flow.", J. Fluid Mech., 361, $297-308,1998$.

6. Nagib H.M., Lavan Z., Fejer A. A. and Wolf L. "Stability of pipe flow with superposed solid body rotation.“, Phys. Fluids, 14 (4), 766 - 768, 1971.

7. Imao S., Itoh M. and Harada T. "Turbulent characteristics of the flow in an axially rotating pipe.", Int. J. Heat and Fluid Flow, 17 (5), 444 - 451, 1996.

8. Facciolo L., Tillmark N., Talamelli A. and Alfredsson P.H. "A study of swirling turbulent pipe and jet flows.“, Phys. Fluids, 19, 035105, 2007.

9. Bell J.H. and Mehta R.D. "Contraction design for small low-speed wind tunnels.”, NASA-CR-182747, 1988.

10. Draad A.A., "Laminar-Turbulent Transition in Pipe Flow for Newtonian and Non-Newtonian Fluids.”, TR DISS 2779, ISBN 90-370-0140-8, Ponsen \& Looijen, 1996.

11. Laws E.M. and Livesey J.L. "Flow through screens.”, Ann. Rev. Fluid Mech., 10, 247 - 266, 1978. 
12. Matsson J.E. “An Introduction to SolidWorks ${ }^{\circledR}$ Flow Simulations 2013.”, SDC Publications, 2013.

13. McKeon B.J et al. "Friction factors for smooth pipe flow.", J. Fluid Mech., 511, 41 - 44, 2004.

14. Swanson C.J., Julian B., Ihas G.G.. and Donelly R.J. "Pipe flow measurements over a wide range of Reynolds numbers using liquid helium and various gases.", J. Fluid Mech., 461, 51-60, 2004. 